\title{
Farmer`s Perception about Resurgence of Brown Planthopper, Nilaparvata Lugens (Stål) in Bangladesh
}

\author{
A B M A Uddin¹, K S Islam², M Jahan², A Ara ${ }^{3}$ and S Afrin ${ }^{4}$
}

\begin{abstract}
Studies were conducted on resurgence of brown planthopper (BPH), Nilaparvata lugens (Stål) and its possible management through a survey in six different regions (viz Tanore, Rajshahi; Niamatpur, Naogaon; Nachole, Chapai Nawabganj; Sadar, Dinajpur; Tarash, Sirajganj and Trishal, Mymensingh). Farmer's perception of BPH resurgence and its management was more or less similar in different regions with some exception. About $60 \%$ farmers were able to identify $\mathrm{BPH}$ and $40 \%$ farmer could identify the pest problem at the later stage of the infestation when burning symptom was visible in patches. All the respondent farmers $(100 \%)$ relied on use of insecticide where the selection of insecticide as well as its application was not appropriate.
\end{abstract}

Key words: Brown planthopper, resurgence, farmer`s perception

\section{INTRODUCTION}

Insect pests and diseases are the important limiting factors of rice production in Bangladesh. Among the pests of rice, the brown planthopper (BPH), Nilaparvata lugens (Stål.) (Homoptera: Delphacidae) has gained major importance in several Asian countries including Bangladesh. The control of this insect pest has always been emphasized and largely relied on insecticides in most rice producing countries (Ali et at., 2019: Wojciechowska et al., 2016; Alam, 2013; Gao et al., 1987; Nagata et al., 1979) where resistant varieties are not available. In Bangladesh, a number of insecticides are being used to control this particular insect pest.

All the pesticides have different types of effect on the pest, which may lead to the differential development of the next generation of the pest. Heavy uses of broad spectrum chemicals also reduce the biodiversity of natural enemies, lift the natural control, induce outbreak of secondary pests and contaminate eco-system (Singh, 2000).
After application of insecticides, $\mathrm{BPH}$ resurgence was reported in Bangladesh (Alam, 2013; Alam and Karim, 1977), India (Ghosal and Chatterjee, 2018; Varadharajan et al., 1977, Chandy, 1979), Indonesia (Oka, 1991; Soekarna, 1979), the Philippines (Heong and Hardy, 2009), Poland (Wojciechowska et al., 2016) and the Solomon lslands (Stapley et al., 1979). Most of the hopper burned fields reported or observed in India, Indonesia, Philippines, and Sri-Lanka received insecticides before the outbreak. In insecticide trials on experiment at stations and in farmer's fields, hopper burn commonly occurs in treated plots while untreated areas remain relatively free of infestation.

Entomologists and plant protection researchers at home and abroad have taken much attention on resurgence of insect pests after application of some insecticides (Wojciechowska et al., 2016; Alam, 2013). Some of the researchers (Bommarco et al., 2011; Flávio et al., 2010; Hajek, 2004; Zhang et al., 1988) thought that resurgence of insect pests might be happened because a number of 
natural enemies were killed by some insecticides. Some of the researchers thought that it probably resulted from stimulated fecundity of certain pests after the applications of some insecticides. International Rice Research Institute (IRRI) widely studied the resurgence of $\mathrm{BPH}$ population and pointed out that the cause of resurgence of $\mathrm{BPH}$ was that natural enemies were killed or plants which grew luxuriantly attracted pests. Another report from IRRI in 1980 indicated that 16 kinds of insecticides could result in resurgence of $\mathrm{BPH}$, and suggested that it was not the principal cause of resurgence for insecticides to kill predators. Some researchers also reported the problem of $\mathrm{BPH}$ in China (Heong and Hardy, 2009; Gu, 1984; Gao et al., 1988).

Improper methods of application of some insecticides also caused resurgence. According to IRRI report (1977), application of Furadan on crop leaf resulted in resurgence of BPH. But application of Furadan on soil didn't result in resurgence (Gao Chunxian et al., 1988), because it made predators and parasites not to come into contact with insecticide and protected them. However, the reason behind the outbreak of BPH in Bangladesh is not well understood.

To find out the reasons for resurgence a survey was conducted on the farmer's perception about brown planthopper resurgence.

\section{MATERIALS AND METHODS}

The survey was carried out at six districts of Bangladesh to study on the farmer perception about brown planthopper $(\mathrm{BPH})$ resurgence in T. Aman season 2014.

There are three methods by which survey data can be gathered (Dillon and Hardaker, 1993). These are i. Direct observation; ii. Interviewing of respondents and iii. Records kept by respondents. Since the farmers of Bangladesh do not usually maintain records, the second method was followed to achieve the objectives. However, survey method is not free from drawback. The main drawback of this method is to rely on the memory of the respondents. To minimize errors, repeated visits were made to collect data and in case of any omission or contradiction the farmers were revisited to obtain the missing and/or correct information.

Selection of the study area. The areas where brown planthopper resurgence was reported in transplanted Aman season 2014 were selected for survey. A lot of news were published in several local and national newspaper of Bangladesh about the resurgence of brown planthopper (Table 1). On the basis of severity of attack and the communication facilities, six upazilas of six districts namely: Tanore, Rajshahi; Niamatpur, Naogaon; Nachole, Chapainawabganj; Tarash, Sirajganj and Trishal, Mymensingh were selected.

Period of survey. The survey was done in T. Aman, during the period from October to November 2014, when the rice crop was at booting to harvesting stage.

Selection of farmers. Farmers who cultivate irrigated rice in the dry and intermediate zones and favourable rainfed rice in the wet zone were selected for the survey. A total of 180 farmers were selected for collecting data to fulfil the objective. About 30 farmers, selected at random, were interviewed in an upazila of each district.

Survey instrument/questionnaire. In conformity with the objectives of the study, a preliminary questionnaire was designed for collecting data from the selected farmers. The draft questionnaire was pre-tested with a few sample farmers of the study areas. Thus, some parts of the draft questionnaire were improved, rearranged and modified in the light of the actual and practical experiences gained from the pre testing. The questionnaire was finally developed in a simple manner, so 
that accurate information could be obtained without repetition and misunderstanding.

Data collection. The survey was designed to describe the sociodemographic profile of rice farmers in the selected districts, record the agronomic and pest management practices in T. Aman 2014 (July to December 2014), and obtain detailed information about farmers' knowledge and attitudes on insect pests and natural enemies of rice and their use of pesticides. Their knowledge in traditional pest control methods was also inquired. Detailed information on the use of insecticide such as product name, manufacturer, group, technical grade (a. i. \%), frequency and time of application and doses of insecticide were recorded.

Date processing. The collected data were coded, summarized and processed for analysis. Data were also verified to eliminate possible errors and inconsistencies. The first step was taken to scrutinize the data of each and every schedule to find out any inconsistency or omission in the data collection and to avoid irrelevant information.

Statistical analysis. After completing the pre-tabulation task, actual tabulation work was started. Processed data were transferred in excel worksheet. Simple statistical analysis, such as percentage, mean, standard deviation (SD), coefficient of variation $(\mathrm{CV})$, standard errors (SE) were determined for the interpretations of the findings of the study.

\section{RESULTS}

\section{Farmer's Knowledge about identification of} brown planthopper (BPH)

Table 2 presents of farmers, knowledge about identification of BPH. Among the six districts, the highest number of farmers, able to identify the brown planthopper was found in Sirajganj (Tarash) and the lowest was found in Mymensingh (Trishal). In Sirajganj 80\% farmers told that $\mathrm{BPH}$ is a serious pest of rice and $20 \%$ farmers had no knowledge about $\mathrm{BPH}$. In Mymensingh the knowledge level of the farmer about $\mathrm{BPH}$ was very poor, which was just opposite scenario of Sirajganj. About $80 \%$ farmers had no knowledge of $\mathrm{BPH}$ in that surveyed area of Mymensingh. In other four districts, above $50 \%$ farmers were efficient in identifying the pest brown planthopper.

Table 1. List of local and national newspapers those published the news of BPH resurgence in 2014.

\begin{tabular}{|c|c|c|}
\hline Newspaper & $\begin{array}{l}\text { Date of } \\
\text { publication }\end{array}$ & Title \\
\hline Alokito Bangladesh & 16.11 .2014 & Rajshahite dhan khete poker akromon \\
\hline Janakantha & 16.05 .2014 & Sugandhi atoper khete pokai biborno \\
\hline Sonar Desh & 18.11.2014 & Tanore chini atob dhane current poker akromon \\
\hline Jugantor & 14.10 .2014 & Barendro anchole aman khete karant poker akromon \\
\hline Bonik Barta & 26.10 .2014 & Poker akromone dishahara dinajpurer krishak \\
\hline Daily Sangram & 24.10.2014 & Dinajpur o Nilphamarite poker akromone krishekra dishahara \\
\hline Daily Naya Digonta & 24.10.2014 & Dinajpur o porshai dhankhete current poka: krishak dishahara \\
\hline Daily Prothom-Alo & 29.10 .2014 & $\begin{array}{l}\text { Dinajpure current poker akroman } \\
\text { koiksho acre aman dhan nosto }\end{array}$ \\
\hline Daily Sanbad & 13.11.2014 & 'Gach foring' niontrone trisale nana uddug \\
\hline Doinik Sodas sangbad & 13.11.2014 & Aman dhane badami gach foring \\
\hline $\begin{array}{l}\text { Doinik Bishsar } \\
\text { Mukhopatro }\end{array}$ & 13.11.2014 & Aman dhane badami gach foring akromon: potirodhe trisala squard goton \\
\hline Amar Desh & 8.11 .2014 & $\begin{array}{l}\text { Mymensinghe dhan khete poker akromon: aman utpadon ordhake neme ashar } \\
\text { asonka }\end{array}$ \\
\hline Doinik Jahan & 8.11 .2014 & $\begin{array}{l}\text { Bivinno upazilai poker akromon } \\
\text { aman phosolar bapok khoti }\end{array}$ \\
\hline
\end{tabular}


Table 2. Ability of farmers of different areas in identifying brown planthopper.

\begin{tabular}{|c|c|c|c|}
\hline \multicolumn{2}{|c|}{ Location } & \multicolumn{2}{|c|}{ Identifying ability of respondent farmers } \\
\hline District & Upazila & Able to identify (\%) & Unable to identify (\%) \\
\hline Rajshahi & Tanore & 66.67 & 33.33 \\
\hline Naogaon & Niamatpur & 63.33 & 36.67 \\
\hline Chapainawabganj & Nachole & 76.67 & 23.33 \\
\hline Dinajpur & Sadar & 60 & 40 \\
\hline Sirajganj & Tarash & 80 & 20 \\
\hline Mymensingh & Trishal & 20 & 80 \\
\hline
\end{tabular}

- Mean value of 30 farmers in each location

Farmer's understanding about the infestation of brown planthopper

In the survey area, farmers understood the infestation of BPH by some parts of the land were burnt, the presence of insects at the base of the plant and both. The highest number of farmers were found in Mymensingh (76.67 \%) who understood the infestation of brown planthopper as some parts of the land were burnt and the lowest number was in Sirajganj $(13.33 \%)$. In case of insects present at the base of the plant, the highest number of farmers was found in Dinajpur (50\%) and the lowest was in Mymensingh (20\%). In both cases, 43.33 $\%$ farmers of Sirajganj was found to understand the infestation of brown planthopper and only $3.33 \%$ farmers were couscious about it in Mymensingh (Table 3).

Brown planthopper management information In all the survey areas, $100 \%$ farmers used chemical insecticides in controlling brown planthopper. No farmer was found to manage the brown plant hopper by using cultural, biological or any other methods.

Determination of insecticide selection in controlling BPH
Selection of insecticide by the farmer for managing $\mathrm{BPH}$ was varied greatly. Farmers used four different ways such as self, neighboring farmer, insecticide dealer and agriculture officer/DAE personal to select insecticide. In surveyed area $64.94 \%$ farmers selected the insecticide by insecticide dealer and only one fourth farmers $(28.89 \%)$ selected the insecticide with the help of agricultural officer/DAE personnel (Fig. 1). Only 2\% farmers selected insecticide by their own decision and about $4 \%$ selected by the advice of neighboring farmer (Fig. 1).

Table 4 presents the details of insecticide selection by the farmers of different regions. In Mymensingh, the highest number of farmers $(83.33 \%)$ selected insecticide with the help of insecticide dealer in contrast it was the lowest $(40.00 \%)$ in the Sirajganj district. But in case of insecticide selection with the advice of agriculture officer/DAE personal, the highest percentage of farmers (53.33\%) was recorded in Sirajganj district and the lowest (13.33\%) was in Naogaon and Mymensingh.

Table 3. Farmer's perception (\%) about the infestation of brown planthopper.

\begin{tabular}{lcccc}
\hline \multicolumn{2}{c}{ Location } & & Judgment of BPH attack \\
\hline District & Upazila & $\begin{array}{c}\text { Burn symptom in } \\
\text { patches }(\%)\end{array}$ & $\begin{array}{c}\text { Presence of BPH at the } \\
\text { base of the plant (\%) }\end{array}$ & Both (\%) \\
\hline Rajshahi & Tanore & 50.00 & 43.33 & 6.67 \\
Naogaon & Niamatpur & 50.00 & 33.33 & 16.67 \\
Chapainawabganj & Nachole & 20.00 & 46.67 & 33.33 \\
Dinajpur & Sadar & 40.00 & 50.00 & 10.00 \\
Sirajganj & Tarash & 13.33 & 43.33 & 43.33 \\
Mymensingh & Trishal & 76.67 & 20.00 & 3.33 \\
\hline
\end{tabular}

- Mean value of 30 farmers in each location. 


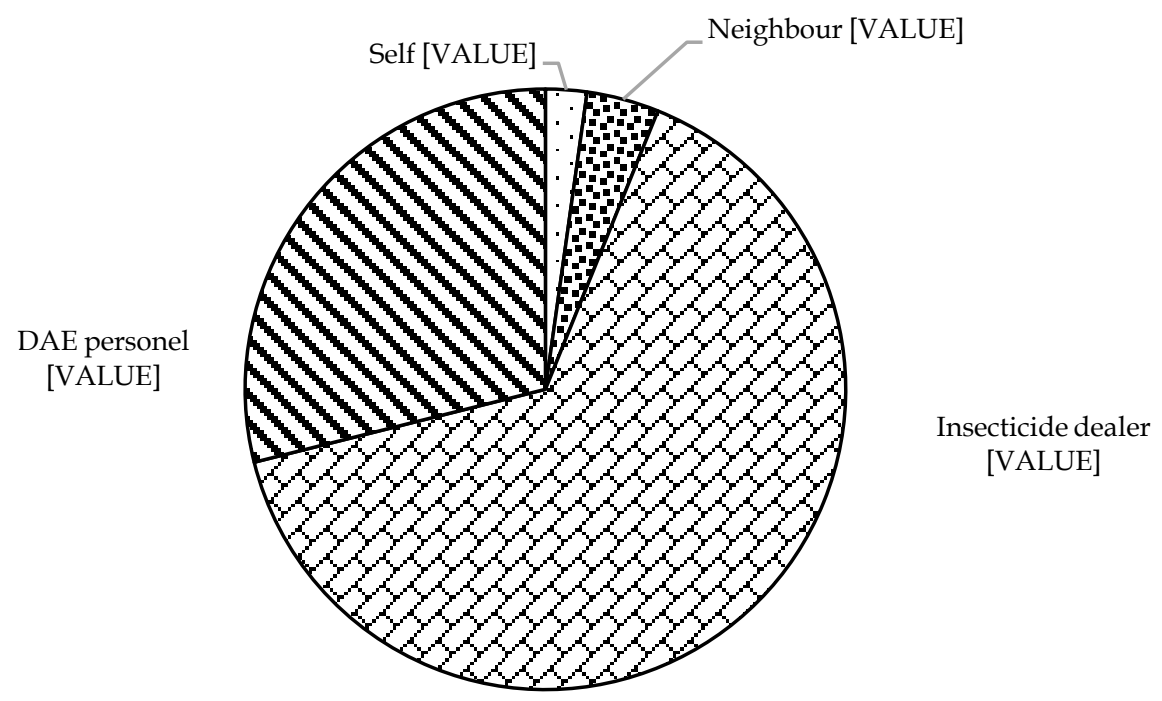

- $\quad$ Fig. 1. Influence of different stakeholders on the insecticide selection by farmers.

Table 4. Influence of stakeholders on farmers insecticide selection decision to manage brown planthopper in different areas.

\begin{tabular}{llcccc}
\hline \multicolumn{2}{c}{ Location } & \multicolumn{4}{c}{ Decision of insecticide selection } \\
\hline \multicolumn{1}{c}{ District } & Upazila & Self (\%) & Neighbor Farmer (\%) & Insecticide dealer (\%) & $\begin{array}{c}\text { DAE } \\
\text { personnel (\%) }\end{array}$ \\
\hline Rajshahi & Tanore & 3.33 & 3.33 & 73.33 & 20.00 \\
Naogaon & Niamat-pur & 3.33 & 6.67 & 76.33 & 13.33 \\
Chapai Nawabganj & Nachole & - & - & 66.67 & 33.33 \\
Dinajpur & Sadar & 3.33 & 6.67 & 50.00 & 40.00 \\
Sirajganj & Tarash & 3.33 & 3.33 & 40.00 & 53.33 \\
Mymensingh & Trishal & - & 3.33 & 83.33 & 13.33 \\
\hline
\end{tabular}

- Mean value of 30 farmers in each location

Insecticide application decision as followed by farmers for BPH management

Among the surveyed farmers larger portion $(62.78 \%)$ sprayed insecticide when $\mathrm{BPH}$ population was over 50 insects per plant and $19.45 \%$ farmers sprayed insecticide when the population level 30 - 50 insects per plants. Only $4.49 \%$ farmers applied insecticide before economic threshold level and $13.34 \%$ at the time of economic threshold level (Fig. 2).

Table 5 presents time of decision about insecticide application in different areas. The highest number of farmers (16.67\%) applied insecticide before economic threshold level (ETL) in Dinajpur district. No farmer was found in the district of Rajshahi, Naogaon, Chapai Nawabganj and Mymensingh to follow the insecticides application before ETL. The farmers of Sirajganj followed ETL in comparatively larger percentage $(46.67 \%)$ and it was minimum (6.67\%) in Rajshahi and Chapai Nawabganj. Insecticide applications at the population level 30-50 BPH/plant was $26.67 \%$ in Dinajpur and Sirajganj and $10.00 \%$ in Naogaon district. Higher percentage of farmers $(80.00 \%)$ in Rajshahi and Naogaon sprayed insecticide when the population of insect was over 50 per plant and the lowest percentage $(16.67 \%)$ followed in the district of Sirajganj. 


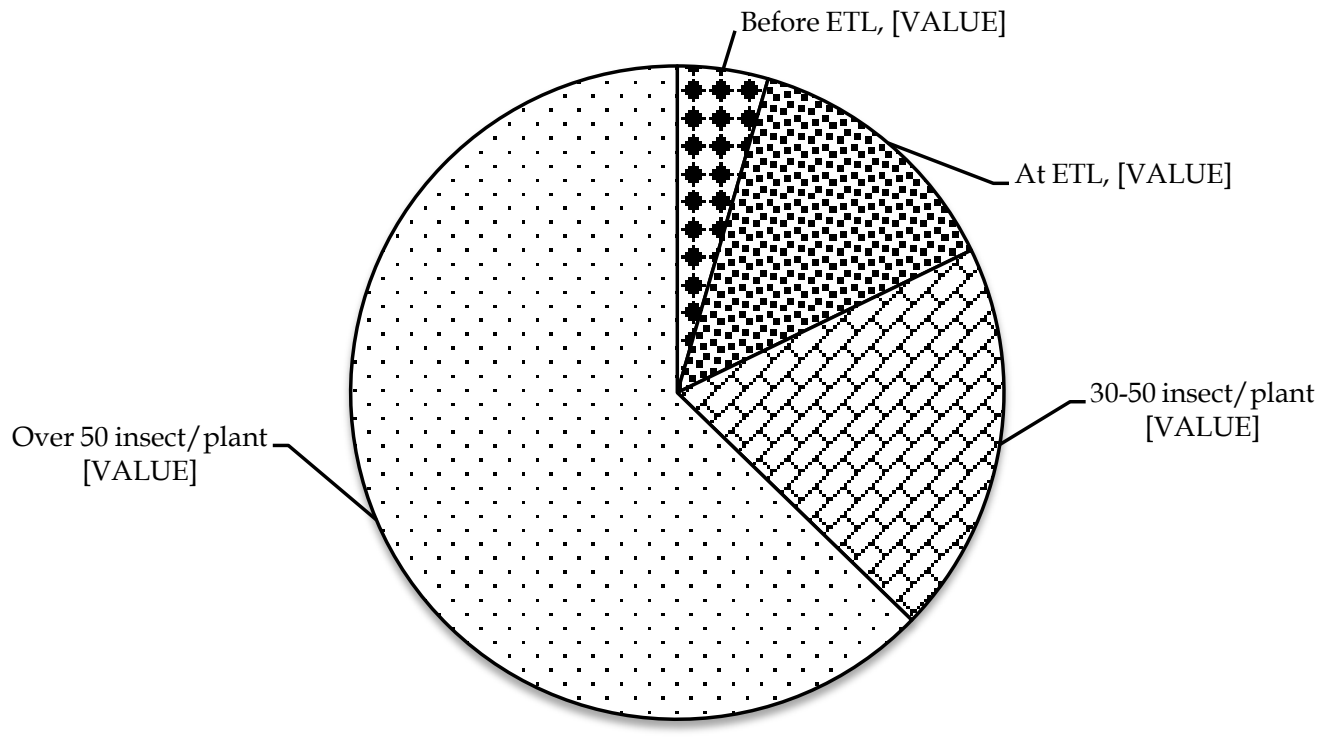

Fig. 2. Farmer's opinion about the insecticide application decision based on level of brown planthopper attack.

Dose of insecticides practiced by farmers to manage the BPH infestation.

Most of the farmers $(44.45 \%)$ in the surveyed areas sprayed insecticide at sub-lethal dose and only $20 \%$ of farmers used to spray at recommended dose (Fig. 3). In the district of Dinajpur, the highest percentage of farmers $(70 \%)$ used sub-lethal dose and it was the lowest $(26.67 \%)$ in Mymensingh (Table 6). Use of over dose was also the highest practice of the farmers of Mymensingh (63.33\%) and the lowest was in Dinajpur (10\%). Comparatively higher percentage of farmer of Sirajganj $(43.33 \%)$ sprayed the insecticide at recommended dose.

Table 5. Farmer`s practice of insecticide application in six districts based on level of brown planthopper attack.

\begin{tabular}{lcccc}
\hline \multicolumn{1}{c}{ Location } & \multicolumn{5}{c}{ Level of BPH attack } \\
\hline \multicolumn{1}{c}{ District } & Before ETL (\%) & At ETL (\%) & $30-50$ insect/plant (\%) & Over 50 insect/plant (\%) \\
\hline Rajshahi & - & 6.67 & 13.33 & 80.00 \\
Naogaon & - & 10.00 & 10.00 & 80.00 \\
Chapai Nawabganj & - & 6.67 & 16.67 & 76.67 \\
Dinajpur & 16.67 & 10.00 & 26.67 & 46.67 \\
Sirajganj & 10.00 & 46.67 & 26.67 & 16.67 \\
Mymensingh & - & - & 23.33 & 76.67 \\
\hline
\end{tabular}

- Mean value of 30 farmers in each location. 


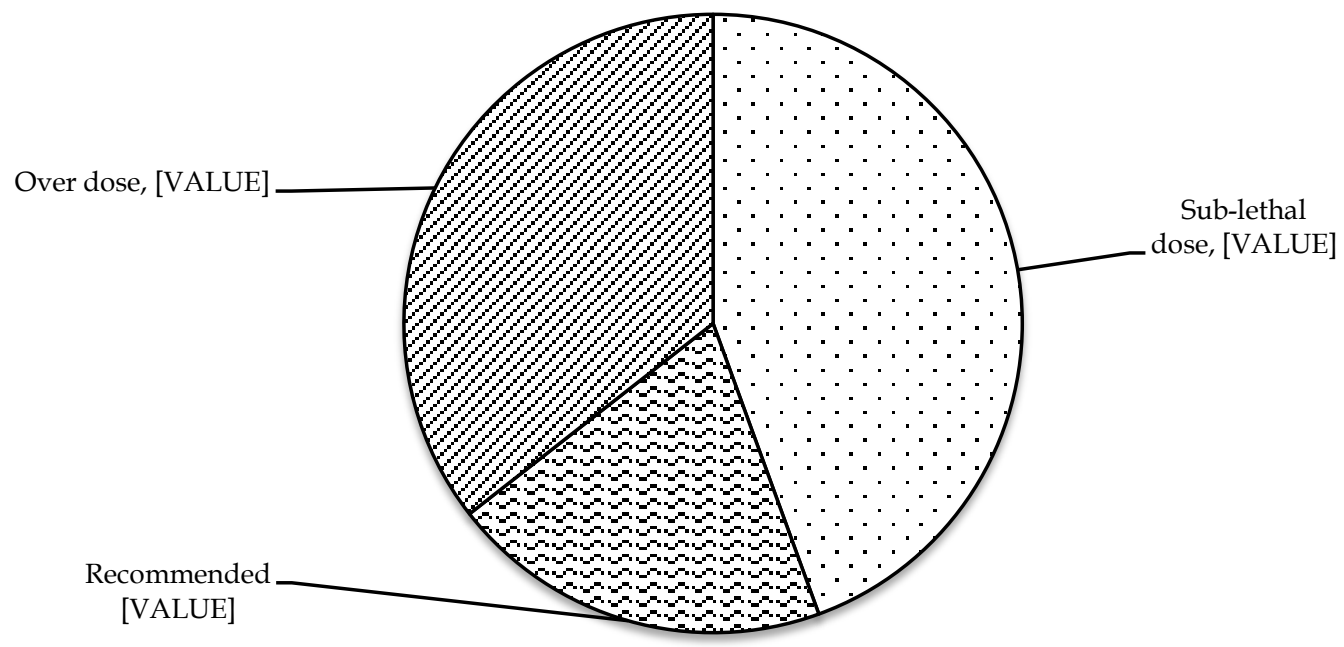

Fig. 3. Farmer`s opinion about insecticide application dose to control brown planthopper in the field.

Spray coverage of insecticide as practiced planthopper at top spectrum, $31.11 \%$ by farmers in controlling BPH Figure 4 farmers followed to cover lower spectrum presents the spectrum of plant coverage. A and only $9.44 \%$ farmer sprayed insecticide large percentage $(59.45 \%)$ of farmers used to spray insecticide in controlling brown at both spectrum for the management of brown planthopper.

Table 6. Opinion of farmers of six locations on the insecticide dose used against brown planthopper.

\begin{tabular}{lccccc}
\hline & Location & & & \multicolumn{3}{c}{ Different dose of insecticide } \\
\cline { 1 - 2 } \cline { 5 - 6 } District & Upazila & & Sub-lethal (\%) & Recommended (\%) & Over (\%) \\
\hline Rajshahi & Tanore & & 56.67 & 13.33 & 30.00 \\
Naogaon & Niamatpur & & 33.33 & 10.00 & 56.67 \\
Chapai Nawabganj & Nachole & & 50.00 & 23.33 & 26.67 \\
Dinajpur & Sadar & & 70.00 & 20.00 & 10.00 \\
Sirajganj & Tarash & & 30.00 & 43.33 & 26.67 \\
Mymensingh & Trishal & & 26.67 & 10.00 & 63.33 \\
\hline
\end{tabular}

- Mean value of 30 farmers in each location. 


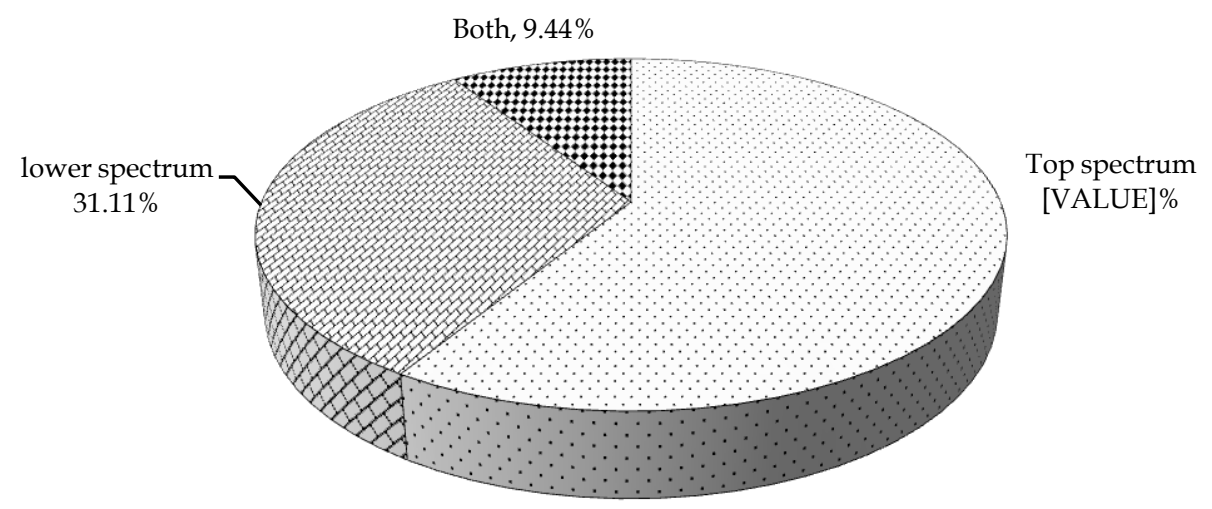

Fig. 4. Spectrum of plant coverage in application of insecticide by the farmer`s in controlling BPH.

Insecticides used in different locations for controlling BPH. Table 7 presents the insecticide molecule used by the farmers in the selected area. From the surveyed area, 16 types of insecticide molecules were reported to be used to control BPH. Among the six districts of six upazila Isoprocarb/MIPC (eg. Mipcin 75WP, Sopcin 75WP, Chabi $75 \mathrm{WP}$ ) was used in most of the time. The highest insecticide was used in Rajshahi (Tanore) and the lowest was used in Sirajganj (Tarash). In Rajshahi, Deltamethrin (eg. Decis 2.5 EC), Imidacloprid (eg. Jadid 200 SL, Imitaf 200SL, Confidor 70WG) and Lambda cyhalothrin (eg. Karate 2.5 EC, Fighter 2.5 EC, Jubas 2.5 EC, Rota, 2.5 EC) were used by the majority of farmers. The highest number of farmers of Naogaon (Niamatpur) and Chapai Nawabganj (Nachole) used Isoprocarb/MIPC (eg. Mipcin 75WP, Sopcin 75WP). Pymetrozine (eg. Pleneum 50 WG) was used by the majority of farmers of Dinajpur (Sadar). In Sirajganj (Tarash) the highest number of farmers used Imidacloprid (eg. Confidor 70WG, Beauty 200SL) and Isoprocarb/MIPC (eg. Sopcin 75WP, Chabi 75WP). The majority number of farmers in Mymensingh (Trishal) used Fenvalerate (eg. Fenfen 20 EC).
Yield loss assessment. The yield loss due to brown planthopper resurgence of the surveyed area was documented as per opinion of the farmers of different regions (Table 8). In Rajshahi, the highest yield loss (23\%) was found in Chini Atop as well as BRRI dhan34 and the lowest yield loss (13.07\%) was in BRRI dhan49. The highest yield loss $(31.70 \%)$ was noted in BRRI dhan34 and the lowest was $(18.51 \%)$ in BRRI dhan49 in Naogaon. Farmers of Chapai Nawabganj opined that the highest yield loss (31.71\%) occurred in Chine Atop and the lowest $(22.81 \%)$ was in Swarna. In Dinajpur, $22.81 \%$ yield loss was estimated in the Swarna and $18.90 \%$ was in BRRI dhan34. The highest $(15.33 \%)$ yield loss was observed in the Swarna in Sirajganj and the lowest was in BRRI dhan49. But in Mymensingh, the highest yield loss (23.94\%) was estimated in BRRI dhan49 and the lowest (15.96\%) was in BINA 7.

Among the surveyed area, the highest yield loss (27.32\%) was found in Chapai Nawabganj (Nachole) and the lowest (13.86 \%) was in Sirajganj (Tarash). Figure 5 presents the amount of yield loss determined according to surveyed area. Fine rice variety showed more yield loss as compared to coarse rice variety. 
Table 7. Pattern of common insecticides use in different locations.

\begin{tabular}{|c|c|c|c|c|c|c|c|}
\hline Insecticide group & $\begin{array}{l}\text { Rajshahi } \\
\text { (Tanore) }\end{array}$ & $\begin{array}{c}\text { Naogaon } \\
\text { (Niamatpur) }\end{array}$ & $\begin{array}{c}\text { Chapai } \\
\text { Nawabganj } \\
\text { (Nachole) }\end{array}$ & $\begin{array}{l}\text { Dinajpur } \\
\text { (Sadar) }\end{array}$ & $\begin{array}{l}\text { Sirajganj } \\
\text { (Tarash) }\end{array}$ & $\begin{array}{l}\text { Mymensingh } \\
\text { (Trishal) }\end{array}$ & Average \\
\hline Acetamiprid & 10.00 & 6.67 & 3.33 & 3.33 & - & - & 3.89 \\
\hline Acephate & 3.33 & 3.33 & 6.67 & 3.33 & - & 6.67 & 3.89 \\
\hline Imidacloprid & 50 & 23.33 & 13.33 & 46.67 & 53.33 & 10 & 32.78 \\
\hline Cartap & 6.67 & 3.33 & 6.67 & 3.33 & - & - & 3.33 \\
\hline Chlorpyrifos & 16.67 & 23.33 & 20.00 & 10.00 & 3.33 & 10.00 & 13.89 \\
\hline Cypermethrin & 23.33 & 13.33 & 3.33 & 3.33 & - & 10 & 8.89 \\
\hline Deltamethrin & 56.67 & 40.00 & 30.00 & - & - & 3.33 & 21.67 \\
\hline Fenvalerate & - & - & - & - & - & 56.67 & 9.45 \\
\hline Isoprocarb/MIPC & 33.33 & 53.33 & 50.00 & 46.67 & 86.67 & 10 & 46.67 \\
\hline $\begin{array}{l}\text { Lambda } \\
\text { cyhalothrin }\end{array}$ & 53.33 & 40.00 & 10 & 23.33 & - & 20 & 24.44 \\
\hline Pymetrozine & 26.67 & 26.67 & 43.33 & 73.33 & 3.33 & & 28.89 \\
\hline Thiamethoxam & 3.33 & 13.33 & 3.33 & 20 & & 3.33 & 7.22 \\
\hline Phenthoate & - & - & - & - & - & 30.00 & 5.00 \\
\hline $\begin{array}{l}\text { Abamectin }(1 \%)+ \\
\text { Acetamiprid }(3 \%)\end{array}$ & 23.33 & 30.00 & 36.67 & - & - & - & 15.00 \\
\hline $\begin{array}{l}\text { Chlorpyrifos }(50 \%)+ \\
\text { Cypermathrin }(5 \%)\end{array}$ & 30.00 & 13.33 & 23.33 & 20.00 & - & 6.67 & 15.56 \\
\hline $\begin{array}{l}\text { Thiamethoxam } \\
(20 \%)+\text { Emamectin } \\
\text { Benzoate }(10 \%)\end{array}$ & 10.00 & 13.33 & 23.33 & 30.00 & - & - & 12.78 \\
\hline
\end{tabular}

- Mean value of 30 farmers in each location.

Table 8. Farmer`s opinion on the yield loss in different rice varieties due to brown planthopper infestation.

\begin{tabular}{|c|c|c|c|c|c|c|}
\hline District & Variety & Land (ha) & $\begin{array}{c}\text { Expected } \\
\text { Yield(ton) }\end{array}$ & $\begin{array}{c}\text { Gained } \\
\text { Yield(ton) }\end{array}$ & $\begin{array}{c}\text { Yield } \\
\text { Loss(ton) }\end{array}$ & $\begin{array}{c}\% \text { Yield } \\
\text { Loss }\end{array}$ \\
\hline \multirow{5}{*}{ Rajshahi } & Swarna & 30 & 180 & 143.42 & 36.58 & 20.32 \\
\hline & BRRI dhan34 & 15 & 52.5 & 40.34 & 12.16 & 23.16 \\
\hline & BRRI dhan 49 & 15 & 82.5 & 71.71 & 10.78 & 13.07 \\
\hline & BINA 7 & 8.44 & 40.51 & 34.05 & 6.46 & 15.92 \\
\hline & Chini Atop & 8 & 28 & 21.51 & 6.49 & 23.17 \\
\hline \multirow{3}{*}{ Naogaon } & Swarna & 15.28 & 91.68 & 73.05 & 18.62 & 20.32 \\
\hline & BRRI dhan34 & 15.28 & 53.48 & 36.53 & 16.95 & 31.70 \\
\hline & BRRI dhan49 & 15.28 & 84.04 & 68.68 & 15.56 & 18.51 \\
\hline \multirow{3}{*}{ Chapai Nawabganj } & Swarna & 20 & 120 & 92.63 & 27.37 & 22.81 \\
\hline & BRRI dhan34 & 20 & 70 & 50.80 & 19.20 & 27.43 \\
\hline & Chini Atop & 8.13 & 28.46 & 19.43 & 9.03 & 31.71 \\
\hline \multirow{2}{*}{ Dinajpur } & Swarna & 9.72 & 58.32 & 45.02 & 13.30 & 22.81 \\
\hline & BRRI dhan34 & 53 & 185.50 & 150.44 & 35.05 & 18.90 \\
\hline \multirow{5}{*}{ Sirajganj } & Swarna & 6 & 36 & 30.48 & 5.52 & 15.33 \\
\hline & BRRI dhan34 & 6.18 & 21.63 & 18.47 & 3.16 & 14.62 \\
\hline & BRRI dhan 49 & 12 & 66 & 59.16 & 6.84 & 10.30 \\
\hline & BINA 7 & 6 & 28.8 & 24.56 & 4.23 & 14.72 \\
\hline & Ranjit & 16 & 96 & 82.23 & 13.77 & 14.34 \\
\hline \multirow{3}{*}{ Mymensingh } & BRRI dhan34 & 7.3 & 25.55 & 19.63 & 5.92 & 23.17 \\
\hline & BRRI dhan49 & 30 & 165 & 125.50 & 39.50 & 23.94 \\
\hline & BINA 7 & 5 & 24 & 20.17 & 3.83 & 15.96 \\
\hline
\end{tabular}

- $\quad$ Mean value of 30 farmers in each location 


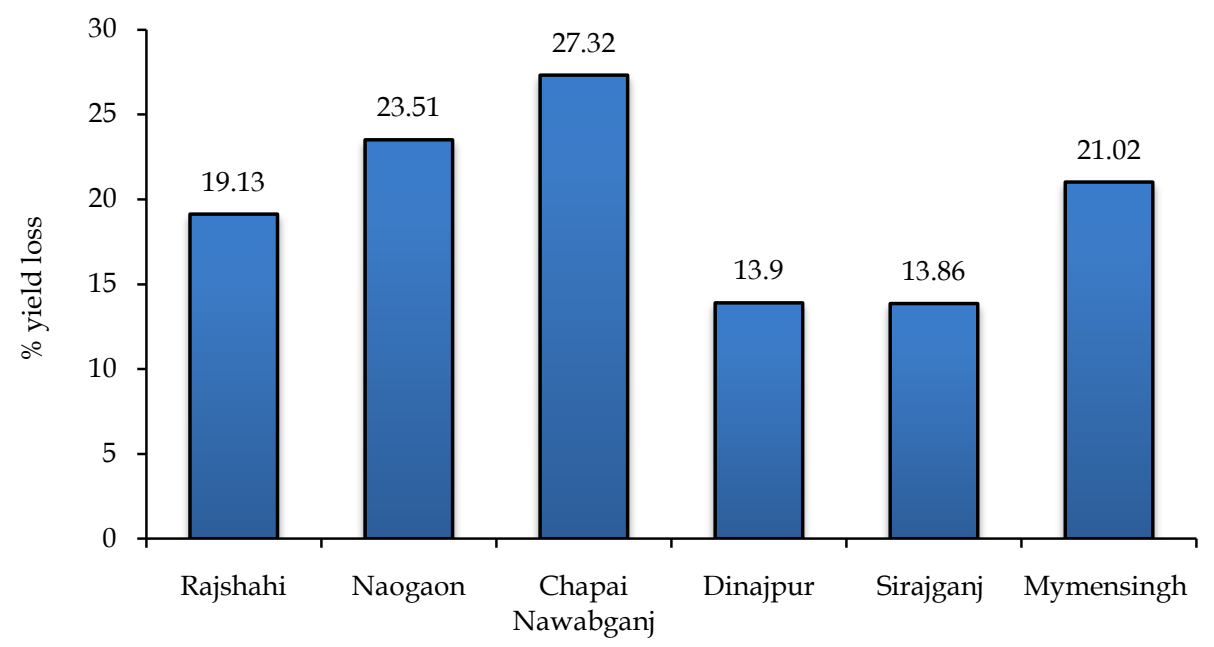

Location (district)

Fig. 5. Average yield loss as estimated by the farmers in different surveyed area in T. Aman season $(\mathrm{N}=30)$.

\section{DISCUSSION}

Knowledge of farmer about identification of $\mathrm{BPH}$ is an important factor for management of $\mathrm{BPH}$ resurgence. In surveyed area, $61.11 \%$ farmers were able to identify BPH and $38.89 \%$ farmers were unable to identify. So there is a lacking about the identification of the pest. In ability of two-third of the farmers could be considered as an important reason of failure for the management of $\mathrm{BPH}$.

Regular monitoring of $\mathrm{BPH}$ population is of great importance for management issue as the pest can build its population in very short period of time. Although monitoring helps the farmer to identify the brown planthopper infestation in early stage, $75 \%$ farmers of the survey area monitor their field occasionally and only $17.78 \%$ farmers practiced monitoring at regular interval. BPH outbreak in the surveyed area is assumed to be due to lack of frequent monitoring. Therefore, identification of initial level of BPH attack and its damage is very much useful for the farmer to manage it successfully. Data on farmers understanding about the infestation of brown planthopper showed that $41.67 \%$ farmers identified the infestation of brown planthopper when some parts of the land were burnt, $39.44 \%$ farmers identified when presence of insects at the base of the plant and $18.89 \%$ farmers identified it is one of the by both conditions. This inability of identifying the damage level or presence of insects in early stage is one of the causes of crop loss due to devastating attack of BPH.

The useful practice of BPH management in all the survey areas was the sole reliance on the use of insecticides. All the farmers (100\%) depended on insecticide to manage the $\mathrm{BPH}$ problem. No mechanical or cultural practice such as light trap, sweep net was used by the respondent farmers in the surveyed area. Although the pest is supposed to be managed by using different management approaches but in practice only pesticide was used against it.

Respondent farmers in the surveyed area used insecticides of different groups to manage the BPH during T. Aman 2014. Among them Isoprocarb/MIPC (eg. Mipcin 75WP, Sopcin 75WP, Chabi 75 WP), 
Deltamethrin (eg. Decis 2.5 EC), Imidacloprid (eg. Jadid 200 SL, Imitaf 200SL, Confidor 70WG, Beauty 200SL), Lambda cyhalothrin (eg. Karate 2.5 EC, Fighter 2.5 EC, Jubas 2.5 EC, Rota 2.5 EC), Pymetrozine (eg. Pleneum 50 WG), Fenvalerate (eg. Fenfen 20 EC) were used by maximum number of farmers. It was evident from the list that many of the insecticides were not recommended against $\mathrm{BPH}$.

Most of the farmers (65\%) selected the insecticides to manage $\mathrm{BPH}$ as per the advice of insecticide dealer. The selection of insecticide through the dealer might have misled the farmers in BPH management. As dealers always motivate the farmers to buy a product which is more profitable for him rather than a recommended one. Only $28.89 \%$ farmers in the surveyed area selected insecticide by the help of the agricultural officer/DAE personal. It was clear from the survey data that high dependency on dealer in selecting pesticide aggravated the problem of $\mathrm{BPH}$ resurgence.

The farmers sometimes do not have ability to pay the cost of insecticide instantly by cash. They frequently collect the pesticide from the dealer living close to his vicinity with the agreement to pay after the harvest. This system might have limitations to select proper insecticide.

Application of only insecticide could be useful in successful control of BPH but it should be applied with right product and dose following right time and method. Insecticide application time is the key factor to manage its infestation. To manage the BPH infestation properly farmers need to apply the insecticide at economic threshold level (ETL). But in the surveyed area, $82.23 \%$ respondent farmers applied the insecticide after ETL. Only 17.83\% applied the insecticide at ETL or before ETL. Heinrichs et at. (1982) reported the timing of insecticide application ultimately governs $\mathrm{BPH}$ resurgence (Heong and Schoenly 1998).
Dose is an important factor to manage the $\mathrm{BPH}$ problem. Most of the farmers (44.45\%) in all the surveyed areas sprayed insecticide at sub-lethal dose and the lowest number of farmers $(20.00 \%)$ sprayed at recommended dose. Most of the farmers did not have the facilities for application of pesticides for which they depend on a professional spray man. Sometimes the professional spray man wants to cover more areas in short period of time rather giving proper concentration to the right dose and coverage at lower spectrum of plants. Use of low dose or sublethal dose contributes significantly in the development of resistance and thereby resurgence (Bottrell and Schoenly, 2012; Way and Heong, 1994; Heinrichs and Mochida, 1984; Chelliah, 1979).

Knowledge on the ecology of pest is necessary to manage a pest. As BPH prefers shady and humid environments for which they are mainly present at the lower spectrum of the plant. Spray of insecticide should thoroughly cover the lower spectrum. But in practice, it is revealed from the farmer's interview that most of the farmers $(59.45 \%)$ sprayed insecticide at the top spectrum and only $32.22 \%$ sprayed their insecticide at lower spectrum of the plant. Coverage of top spectrum application of insecticide failed to reach the body of brown planthopper. That's why application of pesticide did not control the pest rather caused higher crop damage.

Among the surveyed area, the highest yield loss (27.32\%) was found in Chapai Nawabganj (Nachole) and the lowest (13.86 \%) was found in Sirajganj (Tarash). The yield loss of Rajshahi (Tanore), Naogaon (Niamatpur), Mymensingh (Trishal) and Dinajpur (Sadar) were $19.13 \%, 23.51 \%, 21.02 \%$ and $13.90 \%$ respectively. Although none of the cultivated varieties in different areas was resistant or tolerant to $\mathrm{BPH}$ but information generated through farmer's interview indicated that fine rice variety showed more yield loss compare to coarse rice variety. 


\section{CONCLUSION}

Farmers of different regions of the country have lack of knowledge on brown planthopper and its management. That is why the outbreak of $\mathrm{BPH}$ in different regions has been increasing day by day. To manage this detrimental pest, awareness should be developed among the farmers.

\section{REFERENCES}

Alam, M Z. 2013. Survey and assessment of insect management technologies and environmental impact on rice ecosystem of Bangladesh. International Journal of Applied Research and Studies, 2(4): 1-16.

Alam, S and A N M R Karim. 1977. Brown planthopper-a probable threat to rice cultivation in Bangladesh. Paper presented at the 2nd Bangladesh Annual Sci. Conf., Bangladesh Agricultural University, Mymensingh, January, pp. 23-26.

Ali, M P, M N Bari, S S Haque, M M M Kabir, S Afrin, F Nowrin, M S Islam and D A Landis. 2019. Establishing next-generation pest control services in rice fields: eco-agriculture. Scientific Reports, 9:10180 | https://doi.org/10.1038/s41598-019-46688-6.

Bommarco, R, F Miranda, H Bylund, and C B Rkman. 2011. Insecticides Suppress Natural Enemies and Increase Pest Damage in Cabbage. J. Econ. Entomol. 104(3): 782-791.

Bottrell, D G and K G Schoenly. 2012. Resurrecting the ghost of green revolutions past: the brown planthopper as a recurring threat to highyielding rice production in tropical Asia. Journal of Asia-Pacific Entomology, 15:122-140.

Chandy, K C. 1979. Resurgence of brown planthopper. Tamil Nadu Agricultural University Newsl. 9:3.

Chelliah, S. 1979. Insecticide application and brown planthopper, Nilaparvata lugens (Stål) resurgence in rice. A report of research conducted from July 8, 1977 to July 7, 1979. Department of Entomology, International Rice Research Institute, Los Baños, Philippines, $69 \mathrm{p}$.

Dillon, J L and J B Hardaker. 1993. Farm Management Research for Small Farmer Development, FAO, Agricultural Services Bulletin 41, Food and Agricultural Organization of the United Nations, Rome.

Flávio, L F, L Bacci and M S Fernandes. 2010. Impact and Selectivity of Insecticides to Predators and Parasitoids. EntomoBrasilis 3(1): 1-10.
Gao, C X, X H Gu and Y W Bei. 1988. A study on the cause of resurgence of brown planthopper. Acta Ecologica Sinica 8: 155-163.

Gao, H H, Y C Wang, F J Tan and Z P You. 1987. Studies on the sensitivity-level of the brown planthopper, Nilaparvata lugens Stål. to insecticides. Journal of agricultural university. 4:65-71.

Ghosal, A and M Chatterjee. 2018. Insecticide induced resurgence study of whitefly in cotton and tomato. University of Sindh Journal of Animal Sciences, 2 (2): 1-6.

Gu, X H. 1984. Preliminary study of impact of sub-lethal dosages of several insecticides on brown planthopper reproduction. Kunchongzhishi (Entomological knowledge) 6: 276-279.

Hajek, A E. 2004. Natural enemies: an introduction to biological control. Cambridge University Press. Cambridge, UK.

Heinrichs, E A and F G Medrano. 1984. Leersia hexadra, a weed host of the brown planthopper, Nilaparvata lugens (Stål). Crop Protection. 3:77-85.

Heinrichs, E A, G B Aquino, S Chelliah, S L Valencia and W H Reissig. 1982. Resurgence of Nilaparvata lugens (Stål) populations as influenced by methods and timing of insecticide application in lowland rice. Environmental Entomology. 11: 78-84.

Heong, K L and B Hardy. 2009. Planthoppers: new threats to the sustainability of intensive rice production systems in Asia. Los Baños (Philippines): International Rice Research Institute. Pp. 157-178

Heong, K L, and K G Schoenly. 1998. Impact of insecticides on herbivore-natural enemy communities in tropical rice ecosystems. In Ecotoxicology: Pesticides and Beneficial Organisms edited by Haskell, P.T., and McEwen, P. London: Chapman and Hall. pp. 381-403.

IRRI (International Rice Research Institute). 1977. Annual report for 1976. Los Baños, Philippines, 418p.

Nagata, T. 1979. Development of insecticide resistance in the brown planthopper and white backed planthopper. Pp. 107-123 in Sensible use of pesticides. Proc. of a symposium sponsored by FFTC, Taipei. 250p.

Oka, I N. 1991. Success and challenges of the Indonesia National Integrated Pest Management Programme in the rice-based cropping system. Crop Protection, 10(3):163-165.

Singh, S P. 2000. Bio-intensive approach helpful. The Hindu Survey of Indian Agriculture, pp. 159-163.

Soekarna, D. 1979. Time of insecticide application against Nilaparvata lugens- based on population density and the occurrence of resurgence. Proc. Kongress. Entomologi Jakarta, Indornesia. Jan. 9-11. 12p.

Stapley, J H, Y Y Jackson and W G Golden. 1979. Varietal resistance to the brown planthopper in the Solomon 
Islands. Pp. 233-239. In International Rice Research Institute. The brown planthopper: threat to rice production in Asia. Los Baños, Philippines, 369p.

Varadharajan, G, V K R Sathyanandan, S Kandaswamy and M Krishnan. 1977. Possibility of resurgence of the brown planthopper after insecticide treatment. Aduthurai Rep. Nov: pp. 108-110.

Way, M J and K L Heong. 1994. The role of biodiversity in the dynamics and management of insect pests of tropical irrigated rice-a review. Bulletin of Entomological Research, 84:567- 587.

Wojciechowska, M, P Stepnowski, M Gołębiowski. 2016. The use of insecticides to control insect pests. ISSN 1824-307X, ISJ 13: 210-220.

Zhang, C Z, L F Jiang and X D Fan. 1988. Effects of different insecticides on population fluctuations of the rice planthopper and its natural enemies. Zhejiang Academy of Agricultural Sciences. 3: 123-127. 
